DOI

\title{
ОЦІНКА МОЖЛИВОСТЕЙ НЕФРОПРОТЕКТОРНОї ДІї КАНЕФРОНУ® Н У ХВОРИХ НА ПОДАГРИЧНУ НЕФРОПАТІЮ
}

\author{
ОС. І. Сміян, М. В. Франчук, У. С. Слаба, Р. Р. Коморовський, Н. В. Грималюк \\ «Тернопільський державний медичний університет імені І. Я. Горбачевського МОЗ України»
}

\begin{abstract}
РЕЗЮМЕ. Зі стійким підвищенням сечової кислоти в крові ризик розвитку хронічної ниркової недостатності зростає у 3-10 разів. Відомо, що білкові фракції тісно корелюють із рівнем сечової кислоти, і саме тому мікроальбумінурію та мікроглобулінурію вважають ранньою ознакою ураження нирок. Обстежено 50 хворих чоловічої статі на подагру, серед яких шляхом визначення мікропротеїнурії у 60 \% констатовано подагричну нефропатію. Для нефропротекторного лікування обрано комбінований фітопрепарат - Канефрон Н (Біонорика, Ноймаркт, Німеччина), який також позитивно зарекомендував себе у пацієнтів з порушенням ліпідного обміну. Серед пацієнтів, які брали участь у дослідженні, всі були чоловіками з надлишковою масою тіла. Встановлено, що включення Канефрону Н у комплексне лікування разом зі стандартною гіпоурикемічною терапією сприяє достовірному зменшенню рівня сечової кислоти в крові та збільшенню її виведення із сечею, а також чинить нефропротекторну дію, яка проявляється достовірним зниженням мікроальбумінурії та мікроглобулінурії.

КЛЮчОВІ СЛОВА: подагра, ураження нирок, гіперурикемія, Канефрон Н, мікроальбумінурія, мікроглобулінурія.
\end{abstract}

Вступ. Подагрична нефропатія (ПН) включає всю ниркову патологію, яка може бути діагностована при подагрі. У пацієнтів даної когорти найчастіше виявляють уратний нефролітіаз, тофуси в нирковій паренхімі, гломерулосклероз, нефросклероз, інтерстиціальний нефрит, хронічну ниркову недостатність (ХНH) $[2,3,6]$. У 2014 році були розроблені мультинаціональні протоколи лікування подагри, у яких при гострому подагричному нападі рекомендовано використовувати колхіцин у низьких дозах, нестероїдні протизапальні препарати (НПЗП) і / або глюкокортикостероїди, залежно від коморбідних станів [26]. Тому НПЗП займають важливу нішу в симптоматичному лікуванні больового синдрому в пацієнтів 3 подагрою. Відомо, що дана група препаратів має нефротоксичну дію і може призвести до гострого тубулярного некрозу, гострого інтерстиціального нефриту, протеїнурії, артеріальної гіпертензії та гіперкаліємії $[1,23]$. У хворих із супутнім ураженням нирок використання алопуринолу, фебуксостату та бензбромарону $\epsilon$ безпечним і може навіть покращити ниркову функцію $[17,18,31]$.

Згідно з даними літератури, поширеністьПН коливається від $30 \%$ до $70 \%$, аії патогенез пов'язаний з гіперпродукцією СК та дисбалансом між процесами канальцевої секреції та реабсорбції $[10,25]$. На сьогодні невідомо, чи $€$ ГУ маркером ниркової дисфункції, чи фактором ризику розвитку ураження нирок. Такі спірні теорії впливу СК на розвиток хронічної хвороби нирок (XXH) існують зокрема через складність виявлення ПН на ранній стадії, що тривалий час перебігає субклінічно $[2,28]$.

Зі стійким підвищенням СК у крові ризик розвитку ХНН зростає у 3-10 разів, що свідчить про встановлений тісний взаємозв'язок між ГУ та ураженням нирок $[32,33]$. У кожного 4 пацієнта ХНH $\epsilon$ ускладненням подагри. Також ГУ може впливати на гемодинаміку в кортикальному шарі нирок внаслідок вазоконстрикції та збільшити експресію реніну $[2,6,7,22]$.

Відомо, що мікропротеїнурія (МП) $\epsilon$ першою субклінічною ознакою порушення функціонального стану нирок $[13,14,19,29]$. МП - будь-який прояв мікроальбумінурії (МА), мікроглобулінурії (МГ) або їх поєднання. Якщо виявляють МА - це свідчить про ураження клубочків, канальцевий тип порушень характеризується наявністю МГ [20]. Незважаючи на достатність доказової бази про поширення ПН на сучасному етапі існуючі рекомендації ведення та контролю подагри не включають перелік необхідних заходів щодо їх раннього виявлення, жодних превентивних програм і лікування.

Отже, вагомим завданням сучасної ревматології $€$ рання діагностика, профілактика і адекватне своєчасне лікування уражень нирок, які значно впливають на якість і тривалість життя хворих на подагру. Тому метою даного дослідження було визначити поширеність МА і МГ у пацієнтів з подагрою та можливість її корекції.

Матеріал і методи дослідження. Для реалізації мети було обстежено 50 хворих на подагру, які перебували на стаціонарному лікуванні в ревматологічному відділенні КЗ ТОР «Тернопільська університетська лікарня». Усі пацієнти ніколи не отримували профілактичного лікування ПН і не мали ії в структурі діагнозу. Додатково до основних лабораторних та інструментальних методів обстеження у хворих визначали мікроальбуміни 
Огляди літератури, оригінальні дослідження, погляд на проблему

та мікроглобуліни в ранковій порції сечі за допомогою імуноферментного методу та проводили ультразвукове дослідження (УЗД) нирок. Увагу приділяли визначенню індексу маси тіла (IMT), СК плазми крові та сечі, креатиніну, сечовини, швидкості клубочкової фільтрації (ШКФ), УЗД нирок та рентгенологічному обстеженню суглобів. Для використання з нефропротекторною метою обрано комбінований фітопрепарат - Канефрон® Н (Біонорика, Ноймаркт, Німеччина), який також, позитивно зарекомендував себе у пацієнтів 3 дисліпідеміями. До його складу входять трава золототисячника (Centaurium sp.), корінь любистку (Levisticum officinale Koch) і листя розмарину (Rosmarinus officinalis L.) [19]. Канефрон® Н призначали по 2 таблетки 3 рази на день впродовж 6 тижнів. Динамічне спостереження проводили протягом 6 тижнів лікування, після чого повторно визначали рівні мікроальбумінів, мікроглобулінів у сечі та рівні СК у плазмі крові та сечі.

Пацієнти були поділені на 2 групи: хворі I групи ( $\mathrm{n}=25)$ отримували стандартну гіпоурикемічну терапію - Алопуринол, НПЗП та Канефрон Н; хворі II групи ( $=25)$, група контролю, отримували тільки Алопуринол та НПЗП. Усі розрахунки здійснювали на персональному комп'ютері з використанням пакета статистичних програм «Статистика». Вираховували середню величину та її стандартну

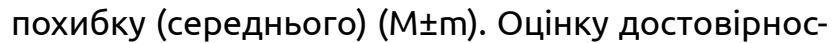
ті проводили за допомогою критерію Манна -Уїтні за показником Р. Різницю показників у групах вважали достовірною при значенні $р<0,05$.

Результати й обговорення. Пацієнти, які брали участь у дослідженні, були чоловічої статі, 3 надлишковою масою тіла, середній вік склав $(54,98 \pm 1,22)$ років, тривалість захворювання $(8,96 \pm 0,57)$ років. Хворі в групах були репрезентативні за віком, тривалістю захворювання та основними параметрами, що вивчалися (табл. 1). За даними УЗД встановлено, що кожний третій пацієнт мав нефролітіаз. Додаткові лабораторні обстеження, а саме визначення рівня МП свідчило, що переважна більшість хворих як I, так і II групи мають ознаки ПН без клінічних проявів (рис. 1).

Таблиця 1. Основні показники захворювання

\begin{tabular}{|c|c|c|c|c|c|c|}
\hline Показники & \multicolumn{3}{|c|}{$\begin{array}{c}\text { Досліджувана група } \\
(n=25)\end{array}$} & \multicolumn{3}{|c|}{$\begin{array}{c}\text { Група контролю } \\
(n=25)\end{array}$} \\
\hline Вік, p & \multicolumn{3}{|c|}{$54,98 \pm 1,22 *$} & \multicolumn{3}{|c|}{$50,63 \pm 1,19$} \\
\hline Тривалість захворювання, р & \multicolumn{3}{|c|}{$8,96 \pm 0,57$} & \multicolumn{3}{|c|}{$7,42 \pm 1,43$} \\
\hline IMT & \multicolumn{3}{|c|}{$28,64 \pm 0,61$} & \multicolumn{3}{|c|}{$30,62 \pm 1,37$} \\
\hline Креатинін, ммоль/л & \multicolumn{3}{|c|}{$72,12 \pm 0,39 *$} & \multicolumn{3}{|c|}{$78,31 \pm 1,21$} \\
\hline Сечовина, ммоль/л & \multicolumn{3}{|c|}{$5,05 \pm 0,65$} & \multicolumn{3}{|c|}{$4,96 \pm 0,27$} \\
\hline ШКФ, мл/хв & \multicolumn{3}{|c|}{$130,88 \pm 1,22$} & \multicolumn{3}{|c|}{$129,64 \pm 0,31$} \\
\hline СК крові, ммоль/л & \multicolumn{3}{|c|}{$558 \pm 0,82 *$} & \multicolumn{3}{|c|}{$551 \pm 1,29$} \\
\hline \multirow{2}{*}{ Ro стадія, \% } & 1 & II & III & 1 & II & III \\
\hline & 11,4 & 79,5 & 9,1 & 11,8 & 76,5 & 11,7 \\
\hline
\end{tabular}

Примітка. * - достовірність між показниками I i II груп $(p<0,05)$.

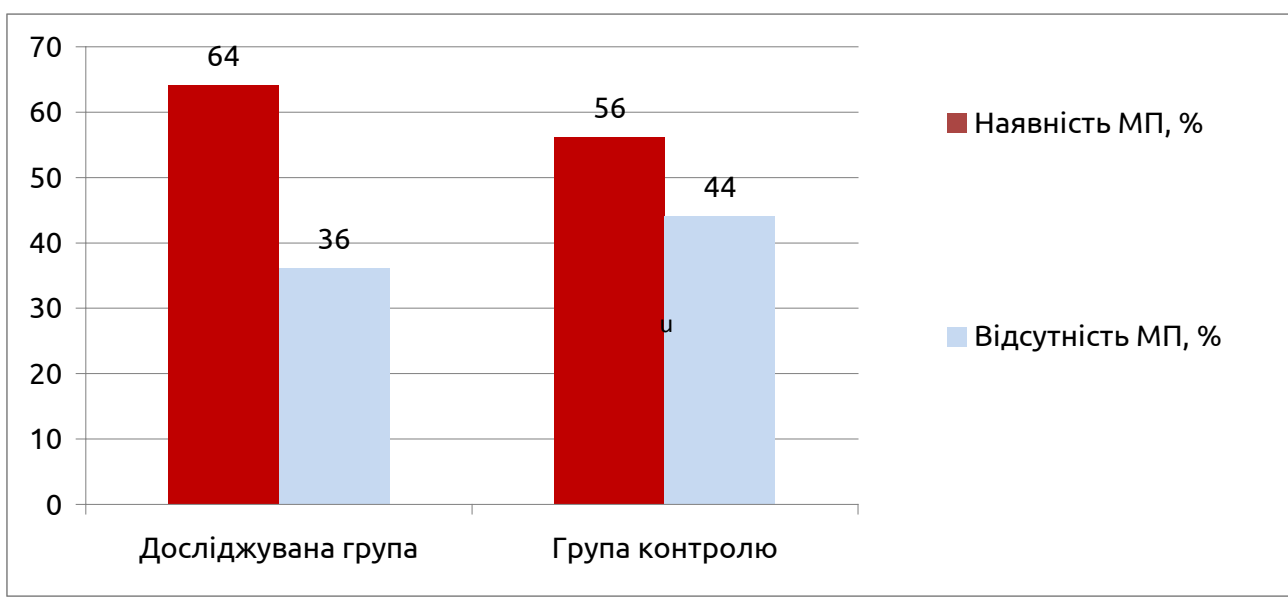

Рис. 1. Мікропротеїнурія у хворих на подагру. 
Огляди літератури, оригінальні дослідження, погляд на проблему

У І досліджуваній групі $48 \%$ пацієнтів демонстрували МА і $60 \%$ - МГ, у ІІ групі - 44 \% і 52 \% відповідно. Динамічне спостереження за основними клініко-лаборатоними параметрами свідчило, що пацієнти, які отримували в комплексній терапії Канефрон Н, мали кращі результати лікування, ніж хворі з групи контролю, які отримували стандартне лікування. Слід зазначити, що під впливом модифікованого лікування суттєво, майже удвічі знижувалися показники МА і МГ (рис. 2), а також значуще зменшувався рівень СК у крові (рис. 3) i збільшувалося її виведення із сечею (рис. 4).

Висновок. Беручи до уваги той факт, що основними ранніми симптомами ниркової дисфункції $\epsilon$ МА та МГ, встановлено, що поширеність ураження нирок у хворих на подагру значно $(p<0,05)$ перевищує констатацію ПН в рутинній клінічній практиці. Креатинін крові, сечовина та ШКФ $\epsilon$ неінформативними показниками функціонального стану нирок на етапі формування ПН, що має субклінічний перебіг. Переважна більшість хворих 3 ПН мали неконтрольовану гіперурикемію.

Встановлено, що включення Канефрону Н у комплексне лікування поряд із стандартною гіпоурикемічною терапією сприяє достовірному зменшенню рівня СК в крові і збільшенню його виведення із сечею, що, в свою чергу, свідчить за плейотропні ефекти даного препарату, які, можливо, пов'язані з різними видами дії Канефрону Н та обумовлені його складниками, такими як ефірні масла, фенолкарбонові кислоти, фталіди, гіркоти. Наприклад, діуретична дія препарату пояснюється поєднанням різних точок прикладання його компонентів. Ефірні масла розширюють судини

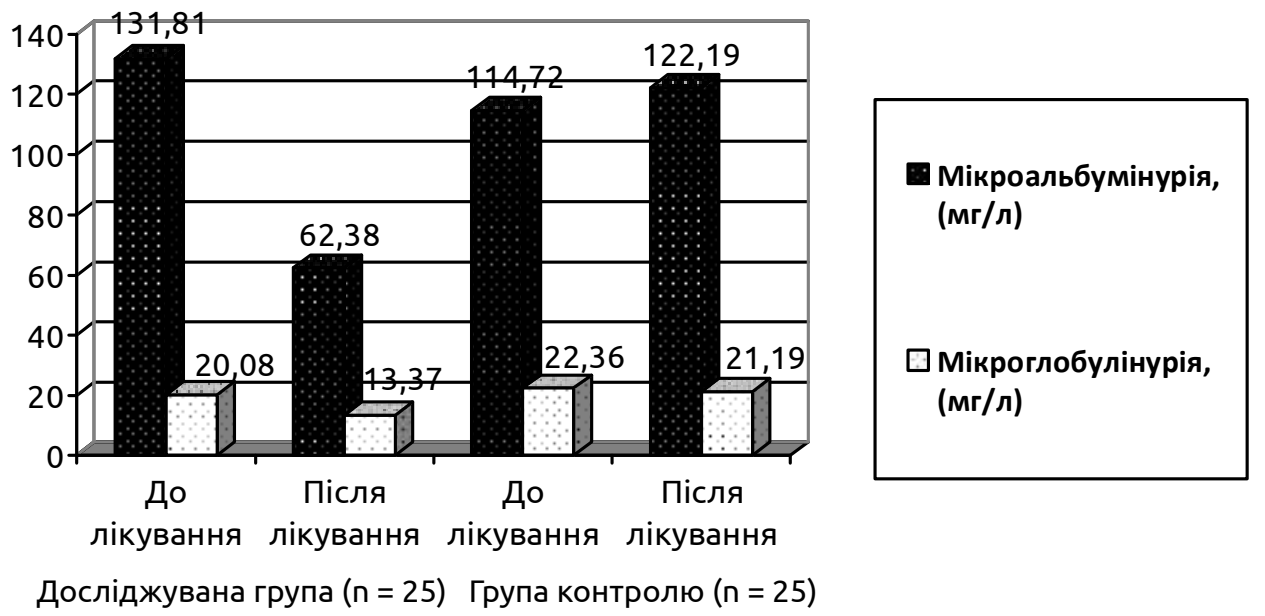

Рис. 2. Зміни мікропротеїнурії після модифікованого лікування Канефроном Н (досліджувана група) та стандартної гіпоурикемічної терапії (група контролю).

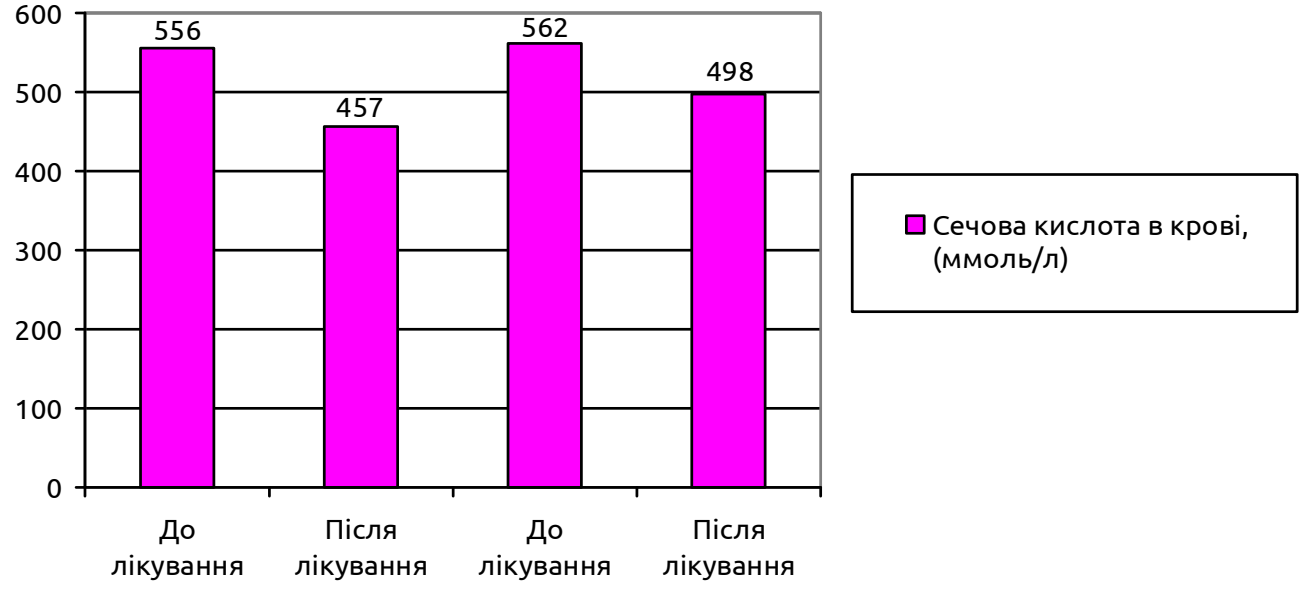

Досліджувана група ( $\mathrm{n}=25)$ Група контролю $(\mathrm{n}=25)$

Рис. 3. Зміни рівня СК у крові після модифікованого лікування Канефроном Н (досліджувана група) та стандартної гіпоурикемічної терапії (група контролю). 
Огляди літератури, оригінальні дослідження, погляд на проблему

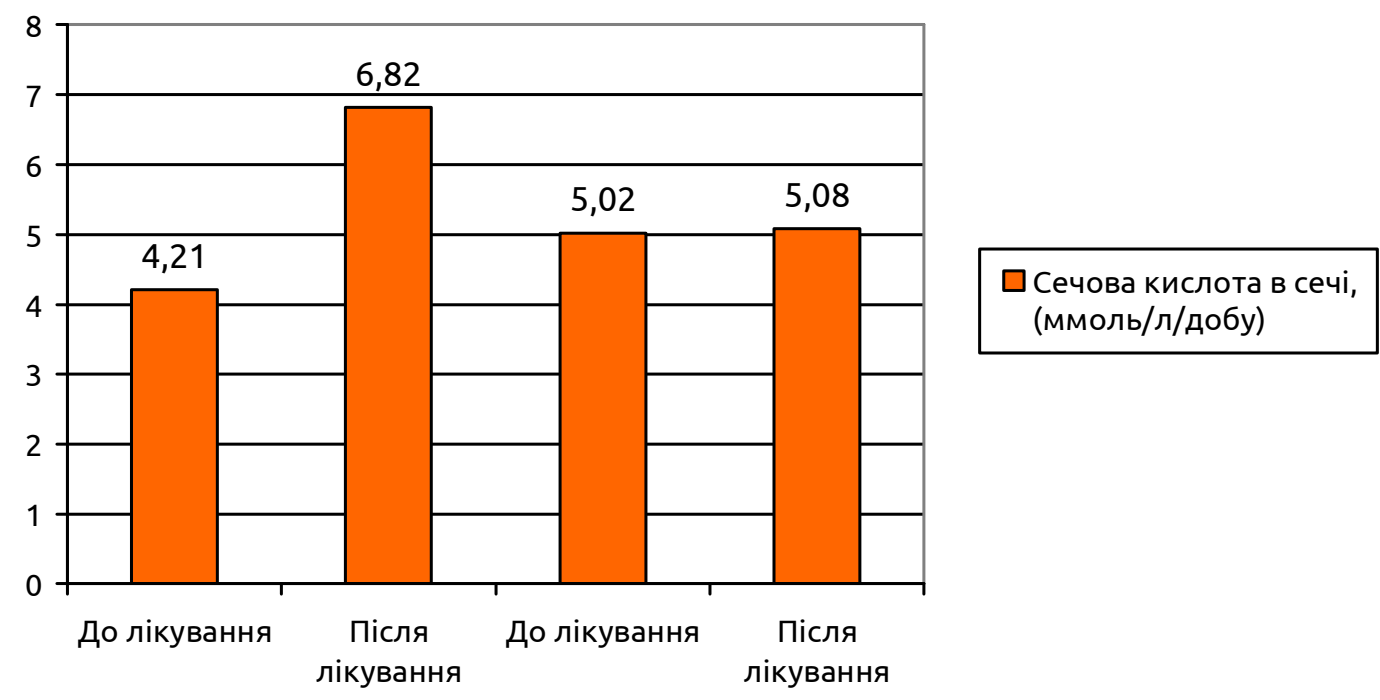

Досліджувана група ( $\mathrm{n}=25)$ Група контролю $(\mathrm{n}=25)$

Рис. 4. Зміни рівня СК у сечі після модифікованого лікування Канефроном Н (досліджувана група) та стандартної гіпоурикемічної терапії (група контролю).

нирок, що сприяє поліпшенню кровопостачання ниркового епітелію, а також впливають на процеси зворотного всмоктування клітинами ниркових канальців. Це проявляється основним чином у зменшенні реабсорбції іонів натрію та відповідної кількості води. Діуретична дія фенолкарбонових кислот пояснюється осмотичним ефектом: при попаданні в просвіт ниркових канальців вони створюють високий осмотичний тиск (зворотному всмоктуванню ці речовини не піддаються); при цьому значно знижується реабсорбція води та іонів натрію. Таким чином, збільшення виведення води відбувається без порушення іонного балансу (калійзберігаючий ефект). Встановлено також, що Канефрон Н посилює виведення со-

\section{ЛІТЕРАТУРА}

1. Амиров Н. Б. Нарушения пуринового обмена гиперурикемия, подагра и их осложнения в общеклинической практике (клиника, диагностика, лечение, профилактика) / под ред. Н. Б. Амирова. - Казань : Медицина, 2010. - 44 с.

2. Джонназарова Д. Х. Клинико-функциональное состояние почек при подагре у жителей республики Таджикистан / Д. Х. Джонназарова : автореферат, 2013.

3. Нарушения пуринового обмена и подагрическая нефропатия [Електронний ресурс]. - Режим доступу : URL : http://www.lvrach.ru/2006/10/4534541/).

4. Шуба Н. Влияние комплексного фитопрепарата Канефрон К на уровень мочевой кислоты у пациентов с гиперурикемией и артериальной гипертензией / Н. Шуба, Т. Воронов, Н. Ткаченко // ML - 2011. - № 1 (77). - С. 77-79.

5. Anticonvulsant effects of some Arab medicinal plants / A. S. Abdul-Ghani, S. G. El-Lati, A. Sacaan [et al.] // Int. J. Crude Drug. Res. - 1987. - № 25. - C. 39-43. лей СК. Ця сторона дії лише частково пов'язана із сечогінним ефектом і досить специфічна. Посилення виділення СК перешкоджає випаданню в сечовивідних шляхах кристалів, зростанню наявних каменів і формуванню нових. Також даний препарат підлужнює сечу, якщо вона різко кисла, і підтримує значення рН в межах 6,2-6,8, що також перешкоджає утворенню уратних каменів. Водночас слід зазначити, що 6-тижневе лікування Канефроном Н, яке було безпечним, без зафіксованих побічних дій, сприяло суттєвому зменшенню рівня МП. Враховуючи все вищенаведене, комбінований фітопрепарат Канефрон Н можна рекомендувати для лікування ПН на етапі її формування за умов збільшення рівнів МА і МГ.

6. Brenner B. M. The kidney 8th edition. Saunders / B. M. Brenner. - Elsevier, 2007. - 1196 p.

7. Disorders of purine metabolism and gouty nephropaty [E-resource]. - Access mode: URL: http://www.lvrach. ru/2006/10/4534541/.

8. European Scientific Cooperative on Phytotherapy. Centaurii herba (Centaury herb). In: ESCOP Monographs. 2nd ed. Stuttgart, Germany, and New York: Thieme-Verlag, 2003. - P. 70-73.

9. European Scientific Cooperative on Phytotherapy. Rosmarini folium (Rosemary leaves). In: ESCOP Monographs. 2nd ed. - Stuttgart; New York : Thieme-Verlag, 2003. - P. 429-436.

10. Gerald D. Fang Effect of Urate-lowering Therapies on Renal Disease Progression in Patients with Hyperuricemia // D. Gerald, R. Nazia, N. Fang // The journal of Rheumatology. - 2014. - P. 955-962.

11. Gracza L. Isolierung von Rosmarinsäure aus Symphytum officinale und ihre antiinflammatorische 
Wirksamkeit in einem In-vitro.Modell / L. Gracza, H. Koch, E. Löffler // Arch Pharm. - 1985. - № 318. - P 1090-1095.

12. Experimental diuretic effects of osmarinus officinalis and Centaurium erythraea / M. Haloui, L. Louedec, B. Michel, B. Lyoussi // J. Ethnopharmacol. - 2000. № 71. $-\mathrm{P}$ 465-472.

13. Hovind P. Serum uric acid as a predictor for development of diabetic nephropathy in type 1 diabetes. An inception cohort study / P. Hovind // Diabetes. - 2009. Vol. 58. - P. 1668-1671.

14. Jalal D. Serum uric acid levels predict the development of albuminuria over 6 years in patients with type 1 diabetes: findings from the coronary artery calcification in type 1 diabetes study / D. Jalal // Nephrol Dial Transplant. - 2010. - № 25. - P. 1865-1869.

15. Bioactivity of secoiridoid glycosides from Centaurium erythraea / Y. Kumarasamy, L. Nahar, P. J. Cox [et al.] // Phytomedicine. - 2003. -№ 10. -P. 344-347.

16. Kumarasamy Y. Bioactivity of gentiopicroside from the aerial parts of Centaurium erythraea / Y. Kumarasamy, L. Nahar, S. D. Sarker // Fitoterapia. - 2003. № 74. - P. 151-154.

17. Urate-lowering therapy for the management of gout: a summary of 2 Cochrane reviews / A. S. Kydd, R. Seth, R. Buchbinder [et al.] // The journal of rheumatology. Supplement. - 2014. - № 92. - P. 33-41.

18. Successful treatment of refractory gout using combined therapy consisting of febuxostat and allopurinol in a patient with chronic renal failure / M. Maekawa, H. Tomida, T. Aoki [et al.] // Internal medicine. - 2014. - № 53 (6). - P. 609-612.

19. Effect of the Herbal Combination Canephron $\mathrm{N}$ on Diabetic Nephropathy in Patients with Diabetes Mellitus: Results of a Comparative Cohort Study / L. Martynyuk, L. Martynyuk, O. Ruzhitska, O. Martynyuk // The journal of alternative and complementary medicine. 2014. - P 1-7.

20. Microalbuminuria [E-resource]. - Access mode: URL: http://www.indap.info/mikroalbuminuriya.html

21. Naber K. G. Efficacy and safety of the phytotherapeutic drug Canephron_ $\mathrm{N}$ in prevention and treatment of urogenital and gestational disease: review of clinical experience in Eastern Europe and Central Asia / K. G. Naber // Res. Rep. Urol. - 2013. - № 5. - P. 39-46.

22. Novitsky V. Pathophysiology / V. Novitsky. - M. : GEOTAR Media, 2009. - T. 2. -848 p.
23. Pascual E. Gout, diuretics and the kidney / E. Pascual, M. Perdiguero // Ann. Rheum Dis. - 2006. - № 65. P. 981-982.

24. Complementdependent stimulation of prostacyclin biosynthesis; inhibition by rosmarinic acid / M. Rampart, J. R. Beetjens, H. Bult [et al.] // Biochem Pharmacol. 1986. - № 35. - P. 1397-1400.

25. Uric acid and chronic kidney disease: which is chasing which? / J. Richard, N. Takahiko, J. Diana, G. Laura [et al.] // Nephrology Dialysis Transplantation. - Vol. 28. Issue 9. - P. 2221-2228.

26. Sivera F., Andres M. [et al.] // Ann Rheum Dis. 2014. № 73 (2). - P. 328-335.

27. Sterner $W$. Studien über die Canephron-Wirkung bei chronischen Nierenerkrankungen / W. Sterner, E. Heisler, H. O. Popp, H. Fischer // Physikalische Medizin Rehabilitation. - 1973. - № 14. - P. 239-258.

28. Association of a Polymorphism in a Gene Encoding a Urate Transporter with CKD Progression / A. Testa, F. Mallamaci, B. Spoto [et al.] // Clinical Journal of the American Society of Nephrology. - 2014. - P. 1059-1065.

29. The study of renal function [E-resource]. - Access mode: URL: http://www.biochemmack.ru/upload/uf/204/ 2042dda688fc61b5d5db08ad2350d6dc.pdf

30. Hydroxyl radical and hypochlorous acid scavenging activity of small centaury (Centaurium erythraea) infusion. A comparative study with green tea (Camellia sinensis) / P. Valentao, E. Fernandes, F. Carvalho [et al.] // Phytomedicine. - 2003. - № 10. -P. 517-522.

31. Treatment of gout patients with impairment of renal function: a systematic literature review / I. A. van Echteld, C. Van Durme, L. Falzon [et al.] // The journal of rheumatology. Supplement. - 2014. - № 92. - P. 48-54.

32. Mild hyperuricemia and subclinical renal damage in untreated primary hypertension / F. Viazzi, G. Leoncini, E. Ratto [et al.] // AJH. - 2007. - Vol. 20. - P. 1276-1282.

33. Weiner D. Uric acid and incident kidney disease in the community / D. Weiner // J. Am. Soc. Nephrol. - 2008. Vol. 19, № 6. - P. 1204-1211.

34. Biologically active principles of crude drugs: pharmacological actions of Swertia japonica extracts, swertiamarine and gentianine / J. Yamahara, I. Konoshima, I. Sawada, H. Fujimura // Yakugaku Zasshi. - 1978. - № 98. P. 1446-1451.

35. Yarnell E. Botanical medicines for the urinary tract/ E. Yarnell // World J. Urol. - 2002. -№ 20. - P. 285-293.

\section{ASSESSMENT OF POTENTIALITIES OF NEUROPROTECTIVE ACTION OF CANEPHRON IN PATIENTS WITH GOUT NEPHROPATHY}

\section{S. I. Smiyan, M. V. Franchuk, U. S. Slaba, R. R. Komorovskyi, N. V. Hrymaliuk Horbachevsky Ternopil State Medical University}

SUMMARY. The risk of chronic kidney failure increases in 3-10 times with the steady increasing of uric acid level in the blood. It is known that the protein fractions are closely correlated with the level of uric acid. Microalbuminuria and microglobulinuria are predictors of kidney damage. The study involved 50 patients with gout who had never received preventive treatment of gouty nephropathy. We chose Canephron N (Bionorica, Neumarkt, Germany) as a combined phytodrug with neuroprotective effect. All studied patients were men with obesity. According to standard examination kidney damage hadn't been found, but laboratory tests on microproteinuria showed that the vast majority of patients had signs of subclinical gouty nephropathy. Canephron $\mathrm{N}$ in complex gout treatment helps to decrease uric acid level in the blood and increase its excretion.

KEY WORDS: gout, chronic kidney disease, hyperuricemia, Canephron N, microalbuminuria, microglobulinuria. 